\title{
American Attitudes toward Free Trade Agreements
}

\author{
Taeeun Min
}

\begin{abstract}
Who are the protectionists in the United States? This paper aims to answer this question. Specifically, I explore whether regional industrial features matter. I also examine whether the economically insecure, who were highlighted as swing voters in the 2016 U.S. presidential election, are protectionists. My empirical findings suggest that American preferences for free trade agreements are decided by economic motives. Specifically, evidence indicates that Americans living in the states with higher shares of manufacturing employment are more likely to hold more negative attitudes toward free trade agreements between the United States and other countries. I also find that all the suggested swing voters in 2016 are not protectionists. Millennials with lower family income are less supportive of trade deals. However, they are not protectionists. In addition, white men with higher, not lower, family income are more likely to see free trade deals as a bad thing.
\end{abstract}

Key Words: American attitudes, protectionism, free trade agreement, manufacturing employment, presidential elections, swing voters

$\mathrm{D}$ uring U.S. presidential campaigns, candidates generally do not criticize either international trade deals or alliance relationships led under U.S leadership. However, the U.S. presidential election of 2016 was an exception to this regular feature of American politics. Along the campaign trail, free trade agreements and alliance relationships in which the United States had taken the lead were questioned by the candidates of both the Democratic and Republican parties. Particularly, during the primary, Democrat Bernie Sanders and Republican Donald Trump blamed U.S free trade deals-such as the 1994 North American Free Trade Agreement (NAFTA), the Korea-US Free Trade Agreement (KORUS FTA) and the Trans-Pacific Partnership (TPP)-as sources

*Taeeun Min(taeeunmnin@gmail.com) is a research fellow in Korea Institute for National Unification(KINU). Her research area is American politics and American foreign policy. Her research topics are particularly focused on public opinion, election and minority politics. 
for America's job losses and trade deficits. The two candidates promised that their government would secure jobs through protection of the U.S economy from unfair trade agreements. Even Hillary Clinton, the Democratic presidential nominee who had supported NAFTA, said that she would re-examine free trade deals if elected.

The underlying assumption of this criticism of free trade agreements is that the public shares the candidates' concerns. What groups of Americans then are against U.S. free trade deals? In other words, who are the protectionists in the United States? This paper aims to answer this question. My particular interest lies in examining whether regional industrial characteristics matter. Specifically, I attempt to investigate whether individuals living in states with a high share of manufacturing industry are protectionists. In addition, I examine whether the economically insecure, known as swing voters in the 2016 election, were more likely to be protectionists. ${ }^{1}$ While answering these questions, I further discuss whether protectionist sloganeering was a successful strategy for winning that election.

According to a public opinion survey released by the Chicago Council on Foreign Affairs in October 2016, 57 percent of the U.S. public think that trade is good for the U.S. economy and American companies. Also, 70 percent of Americans agree that international trade is good for U.S. consumers. These results show that overall the American public perceives international trade as positive. Then, the concerns candidates had for free trade deals diverge from the opinions of a vast majority of Americans. Then, whom did the candidates go for with protectionist sloganeering?

As mentioned, a majority of the U.S. public supports international trade in general. Then, candidates' protectionist positions may appeal only to a specific segment of voters. One of the strongest nominees for the particular voters are swing voters (undecided voters) who are adversely affected by free trade agreements. During the 2016 election campaign, young people particularly from low-income families, working-class white men, and Latinos were singled out as swing voters. The common denominator of these 2016 swing voters was their economic insecurity. In general, the economically insecure favor protectionism over free trade because free trade might lead to more competition for jobs and income. Therefore, candidates during the 2016 campaign were very likely to seek

1 The term swing voters can be defined and measured in various ways. However, swing voters have been understood as undecided or ambivalent voters in terms of their vote choice (Mayer 2007; Cox 2009; Campbell, Converse, Miller, and Stokes 1960, 77-78; Campbell 2007). In short, swing voters refer to those who are uncertain about whom they will vote for. 
to gain votes from such voters by espousing protectionist positions.

However, in the United States, presidential candidates campaign state by state. Thus, with a particular campaign pledge, it is often easier for candidates to target the electorate in a state than to target scattered voters across the country. That is, with protectionist slogans, it is more effective for candidates to target a state where voters sharing particular characteristics live in clusters. Since the United States is a skill-abundant country, its manufacturing industry is the sector most adversely affected by trade liberalization. This means that free trade agreements can lead the states with a high share of manufacturing industry to lose jobs and income. In other words, free trade deals may constrain a states' economy, including the economic conditions of people living in those states. Then, a campaign slogan promoting protectionism would be very likely to resonate with voters living in states where the share of manufacturing industry is high. This phenomenon would be even more exaggerated if the states were swing states and voters in those states were undecided.

This study analyzes the regional economic context in order to articulate the determinants of American public attitudes toward free trade agreements. Prior studies find that individual economic factors, such as education and income, and psychological factors, such as nationalism, party identification, and ideology, were key determinants of public attitudes toward trade policy (Scheve and Slaughter 2001; Mayda and Rodrik 2005; Kaltenthaler, Gellenery, and Ceccoli 2004; Mansfield and Mutz 2009; Mayda 2006; O'Rouke and Sinnott 2001, 2006). However, individual attitudes toward social and political issues depend on where voters live (Campbell, Wong, and Citrin 2006; Key 1949; Hopkins 2010; Schissel, Wanner, and Frideres 1989). Therefore, this paper will contribute to our understanding of public trade preferences by taking into account regional economic features. Also, this study will help us to better understand the electoral targeting. Throughout the 2016 campaign, it was said that the presidential candidates intended to persuade economically insecure swing voters with protectionist slogans. Hence, this paper will lend insights into whether the candidates correctly targeted those voters.

My empirical findings reveal that American preferences for free trade agreements are determined by economic motives. Industrial features of states and household income also are related to American attitudes toward free trade agreements. Specifically, I find that Americans living in states with higher shares of manufacturing employment are more likely to have negative attitudes towards free trade agreements between the United States and other countries. That is, those living in states with a higher share of manufacturing employment are more likely to be protectionists. Consequently, they were very likely to be persuaded by 
presidential campaign pledges of protectionism in the 2016 election. I also find that all the suggested swing voters of 2016 are not protectionists. Millennials with lower family income are less supportive of free trade deals. However, they are not protectionists. In addition, white males with higher, not lower, family income are more likely to see free trade deals as a bad thing.

Other than economic factors, race and individual evaluations of the national economy are significantly related to American attitudes about free trade agreements. Individuals belonging to major racial/ethnic groups in the United States tend to support free trade agreements. Particularly, Latinos, known as swing voters during the 2016 election, have positive attitudes toward free trade agreements. Also, Americans with positive evaluations of the national economy tend to have positive attitudes.

This paper consists of five sections. In the following, I review the previous literature on public attitudes toward trade policies. Next, I present hypotheses. In the third section, I explain the data and variables used for empirical analyses. In the fourth section, I discuss empirical findings. Lastly, I conclude the paper.

\section{LITERATURE ON INDIVIDUAL TRADE POLICY PREFERENCES}

Studies on individual preferences for trade policies emphasize economic and psychological factors as crucial determinants. They find that individual skills and the sector of employment shape individual attitudes toward trade policies. (Mayda and Rodrik 2005; Mayda 2007; O'Rourke and Sinnott 2001; 2006; O’Rourke and Taylor 2006; Scheve and Slaughter 2001). Scholars also find that national identity and political predispositions influence individual trade policy preferences. In detail, most of the economic explanations posit that individual attitudes toward trade policy are decided by material interests. According to them, self-interested individuals use a cost-benefit approach to decide whether or not to support trade policies. Thus, individuals who gain economic benefits through trade liberalization tend to hold positive attitudes toward open trade policy. These economic explanations are based on the Ricardo-Viner and the Heckscher-Ohlin models of trade.

The two models are designed to explain how international trade affected a country's relative prices of goods and, thereby, personal income. In theory, both models demonstrate that trade liberalization causes the redistribution of income. Specifically, the models assume that international trade causes comparativeadvantage sectors to gain income while it directs comparative-disadvantage sectors to lose income. However, the two models are distinctive in the degree of 
factor mobility.

The Ricardo-Viner model assumes that some factors are sector-specific and immobile across industries. Thus, if an industry in a country is an importcompeting sector that requires immobile sector-specific factors, it will face lower prices and lower profits resulting from free trade. Therefore, its workers will confront lower payments; that is, they will incur income losses. As a result, the industry will prefer protection over free trade. In short, the Ricardo-Viner model posits the type of industrial sector as a crucial determinant for a country's trade policies. Based on the logic of the Ricardo-Viner model, individual preferences for trade policies are decided by their sectors of employment. Specifically, individuals working in importing-competing sectors are inclined to be anti-free trade.

The Heckscher-Ohlin model focuses on factor endowments as key determinants for a country's trade policies. This model assumes that factors are mobile; hence, a country with abundant skilled labor prefers free trade since it can gain comparative advantages from exporting goods produced by that skilled labor. In other words, trade will increase demand for high-skilled products of the country. Instead, the country will import more labor-intensive goods. Thus, those who are highly skilled in a skill-abundant country are more likely to support free trade. In contrast, the unskilled are expected to be more protectionists in a skill-abundant country.

However, most individuals are not well-informed about all of the details of trade policies. In addition, they are uncertain about the consequences of those trade policies on them. As a result, studies find that individuals tend to rely on shortcuts, such as national identity, party identification and political ideology, for forming their attitudes toward trade policies (Daniels and von der Ruhr 2003; Mayda and Rodrik 2005; O’Rourke and Sinnott 2001; Scheve and Slaughter 2010). These longstanding psychological predispositions serve as yardsticks for individuals to arrange the complex contents of a trade deal in an organized way and thereby to form positions toward it. Daniels and von der Ruhr (2003) find that liberals and progressive party identifiers are more likely to be protectionists. Through cross-national analyses, Mayda and Rodrik (2005) and O'Rourke and Sinnott (2001) discover that national identities, such patriotism, nationalism and chauvinism, also are linked to protectionist attitudes.

\section{HYPOTHESES}

According to the logic of the Heckscher-Ohlin model, skilled workers are less 
vulnerable to open trade policies. Thus, they are more likely to support free trade, and empirical findings support this. Skilled individuals tend to support free trade regardless of the factor endowments of their home countries (Baker 2005; Beaulieu, Ravindara, and Wang 2005; Mayda and Rodrik 2005; O'Rourke and Sinnott 2006). In line with the logic of the Heckscher-Ohlin model, I hypothesize that the unskilled are more likely to have protectionist attitudes toward free trade. In addition, I hypothesize that both young voters and white males from low income households are more likely to be protectionists. From the perspective of the Heckscher-Ohlin model, they are assumed to be, in a comparative sense, the unskilled. During the 2016 presidential campaign, free trade deals were condemned as the sources of income and job losses in the United States. In particular, the young and white males with low family income attracted extensive public attention as swing voters who were the most economically vulnerable to free trade. Therefore, I will also test in a separate empirical model whether the young and white males with low family income are protectionists.

The Ricardo-Viner model focuses on sector effects. The model assumes that individuals employed in exporting industries support policies that promote freer trade. In contrast, individuals employed in import-competitive industries oppose free trade and request protections. ${ }^{2}$ My interest lies in the impact of the sectoral features of a state on individual attitudes toward free trade deals. Thus, in line with the logic of the Ricardo-Viner model, I hypothesize that individuals who live in the states with a higher share of manufacturing employment are more likely to be protectionists.

The rationale for using a state's share of manufacturing employment as a proxy for sector effects is that trade policy affects the economic activities of a region as a whole. That is, trade policies affect the demand and prices not only of trade sectors but also of nontrade sectors of a region. Particularly, free trade tends to contract the regional economy all together where import-competing industries play a central role. The negative effects of free trade are expected to become larger when comparative-disadvantaged industries make up a substantial portion of the regional economy. In the case of the United States, the manufacturing sector is representative of an import-competitive-and, therefore,

${ }^{2}$ An individual's type of employment is often used as a measurement to capture the industry-specific effects of trade. However, the survey data used in this study does not contain a question on the type of employment. Thus, the type of industry is not included in the empirical models. Moreover, the employment categories used in many surveys do not match with the type of employment that the Ricardo-Viner model posits (Hiscox 2006). 
comparatively-disadvantaged-industry. When individuals live in a state with a higher share of manufacturing employment, their job opportunities and income will be more adversely affected by statewide income losses due to free trade deals. As a result, those individuals are more likely to be protectionists.

Trade policy preferences also depend on psychological factors. Thus, I test the roles of ideology and party identification. In general, liberals and liberal party identifiers are known to be more protectionists. They are more sympathetic to policies that promote income redistribution from the rich to the poor through government programs (Converse et al. 1960; Daniel and von der Ruhr 2005; McCarty, Pool, and Rosenthal 2006). Free trade agreements may adversely affect the low-skilled with relatively lower income. If so, liberals and liberal party identifiers would be expected to have more negative attitudes toward free trade. In this vein, I hypothesize that Democrats, along with liberals, are more likely to oppose free trade deals.

I also investigate the effects of subjective assessments of economic situations. Free trade makes some people losers, while it makes others winners. Accordingly, trade liberalization can increase an individual's feeling of insecurity (Hay, Ehrlich, and Peinhardt 2005; Warren 1999). Such insecurity can influence an individual's support for open trade. Those making negative evaluations on the personal and national economy are more likely to feel insecure about the consequences of free trade. Hence, I predict that Americans who make negative evaluations of their personal economic situation and the national economy are more likely to be protectionists.

\section{DATA AND VARIABLE DESCRIPTION FOR EMPIRICAL ANALYSES}

In this study, I use data from the May 2015 Pew Research Center Political Survey. The survey interviews 2,002 respondents from across the country. It contains a series of questions relevant for this study. Particularly, it investigates Americans' overall evaluations on free trade deals generally, neither focusing on free trade in abstract terms nor on a single specific trade deal. For the data on the shares of manufacturing employment in 2015, I use data released by Bureau of Economic Analysis. For empirical analyses, I use binary logit analysis because the dependent variable is a dummy variable. 


\section{DEPENDENT VARIABLE}

In this study, the dependent variable is individual attitudes toward free trade agreements. To capture those attitudes, I operationalize the following question: "In general, do you think that free trade agreements between the U.S. and other countries have been a good thing or a bad thing for the United States?" I code responses as one (1) when respondents answered 'good thing' and zero (o) otherwise. This question has an advantage over the question often used to capture public attitudes about specific trade deals. ${ }^{3}$ The question used in this study asks what respondents think about free trade deals in which the U.S has been engaged. That is, the question captures Americans' overall evaluations of free trade deals that the United States has actually been involved in. As shown in Table 1, a majority of Americans thinks free trade agreements as positive. 63 percent of respondents report free trade agreements positively, while 37 percent view them negatively.

Table 1. American Attitudes toward Free Trade Agreements

\begin{tabular}{c|c}
\hline & Frequency (\%) \\
\hline Good thing & $1,158(63)$ \\
Bad thing & $670(37)$ \\
Total & $1,828(100)$ \\
\hline
\end{tabular}

Note: *(\%)

Source: May 2015 Pew Research Center Political Survey

Table 2 shows American attitudes toward free trade agreements by partisanship. As shown, there is no significant difference in attitudes by partisanship. The number of Democratic protectionists is not significantly larger than that of their Republican counterparts.

Table 2. American Attitudes toward Free Trade Agreements by Party Identification

\begin{tabular}{c|c|c|c|c}
\hline & Republicans (\%) & Democrats (\%) & Independents (\%) & Total (\%) \\
\hline Good thing & $276(61)$ & $378(65)$ & $484(64)$ & $1,138(64)$ \\
Bad thing & $177(39)$ & $200(35)$ & $274(36)$ & $651(36)$ \\
Total & $453(100)$ & $578(100)$ & $758(100)$ & $1,789(100)$ \\
\hline
\end{tabular}

Note: * $(\%)$

Source: May 2015 Pew Research Center Political Survey

3 To capture public attitudes toward a specific trade deal, some variation of the following question is often used: 'A free trade agreement with a country is a good thing or a bad thing for a respondent's country?' 
Table 3 shows American attitudes by age group. Overall, the percentage of respondents with pro-trade views gets smaller as respondents get older. In addition, generational difference is observable. 70 of millennials (344 out of 471 millennials), those born after 1980, believe that free trade agreements had been good for the United States. In contrast, 60 percent of non-millennials (814 out of 1,357 non-millennials) saw free trade agreements as positive.

Table 3. American Attitudes toward Free Trade Agreements by Age Group

\begin{tabular}{c|c|c|c|c|c|c|c|c|c}
\hline & $\mathbf{1 8 ~ 2 9}$ & $\mathbf{3 0 \sim 3 9}$ & $\mathbf{4 0 \sim 4 9}$ & $\mathbf{5 0 \sim 5 9}$ & $\mathbf{6 0 \sim 6 9}$ & $\mathbf{7 0 \sim 7 9}$ & $\mathbf{8 0 \sim 8 9}$ & $\mathbf{9 0 \sim 9 9}$ & Total \\
\hline \multirow{2}{*}{ Good } & 225 & 168 & 165 & 198 & 218 & 114 & 55 & 15 & 1,158 \\
& $(76)$ & $(71)$ & $(60)$ & $(59)$ & $(59)$ & $(56)$ & $(65)$ & $(56)$ & $(63)$ \\
& 72 & 68 & 108 & 139 & 151 & 91 & 29 & 12 & 670 \\
Bad & $(24)$ & $(29)$ & $(40)$ & $(41)$ & $(41)$ & $(44)$ & $(35)$ & $(44)$ & $(37)$ \\
& 297 & 236 & 278 & 337 & 369 & 205 & 84 & 27 & 1,828 \\
\hline
\end{tabular}

Note: * $(\%)$

Source: May 2015 Pew Research Center Political Survey

Table 4. American Attitudes toward Free Trade Agreements by Racial Group

\begin{tabular}{l|c|c|c|c|c|c}
\hline & Whites & Blacks & Asians & Latinos & Other races & Total \\
\hline Good thing & $891(63)$ & $113(61)$ & $43(73)$ & $79(75)$ & $13(43)$ & $1,139(63)$ \\
Bad thing & $532(37)$ & $71(39)$ & $16(27)$ & $26(25)$ & $17(57)$ & $662(37)$ \\
& $1,423(100)$ & $184(100)$ & $59(100)$ & $105(100)$ & $30(100)$ & 1,801 \\
& & & & & $(100)$ \\
\hline
\end{tabular}

Note: ${ }^{*}(\%)$

Source: May 2015 Pew Research Center Political Survey

Table 4 reports the American public's attitudes toward free trade agreements by racial group. The percentage of Latinos and Asian Americans who support free trade agreements between the United States and other countries is greater than that of both whites and African Americans. However, across the major racial groups in the United States, the number of supporters for free trade agreements is a lot larger than that of protectionists.

\section{INDEPENDENT VARIABLES}

Economic explanations emphasize individual skills and the type of economic sector as key determinants for individuals' trade policy preferences. Education is the most commonly used measure to identify individual skills (Mayda and Rodrik 2005; Scheve and Slaughter 2001). Thus, to capture an individual's skill level, I use the respondent's level of completed education, ranging from 1 (less than a high school graduate) to 8 (postgraduate or professional degree). 
Regarding sector effects, I investigated how industrial features of a state affect American attitudes toward free trade deals. ${ }^{4}$ To measure the industrial characteristics of a state, I used each state's share of manufacturing employment. Indiana, Wisconsin, Michigan, Iowa, Alabama, Arkansas, Ohio, Kentucky, Mississippi, and Kansas are the top 10 states with the highest shares of manufacturing employment in 2015. Among the 2,002 respondents, 397 (20 percent) live in the top 10 manufacturing states.

Investigating the effects of regional economic characteristics has particular merit in the context of the 2016 presidential election. In all of the top 10 manufacturing states, Trump won. Also, among them, Wisconsin, Iowa, Michigan, and Ohio were considered to be the key swing states throughout the 2016 election campaign. ${ }^{5}$ Accordingly, empirically examining the effects of the manufacturing share variable will help to evaluate whether protectionism successfully mobilized voters in swing states whose key industrial sector was manufacturing, even when other relevant variables were controlled. It will also help to grasp empirically whether protectionism sloganeering contributed to Trump winning the election.

The young and white males with low family income are operationalized by employing two interaction term variables. Specifically, I group the millennial generation, who were born after 1980, as 'the young.' Millennials are coded as one (1); all others as zero (o). Thus, the interaction term the young with low family income is constructed by multiplying respondents' family income by the dummy variable for millennials. ${ }^{6}$ To construct the other interaction term white males with low family income, I multiply the race dummy variable whites (whites $=1$ ) by gender dummy variable (male $=1$ ) and family income. Respondents' income is measured using a nine-point scale. ${ }^{7}$

To capture the subjective effects of psychological factors, I include political

4 The survey did not include a question asking respondents about what sector they were employed in. Thus, I did not test the impact of the sector of employment on individual trade preferences.

5 Swing states change from election to election, although some states, such as Florida have been considered as traditional swing states. In the 2016 presidential election, Florida, Ohio, Pennsylvania, Wisconsin, New Hampshire, Minnesota, Iowa, Michigan, Nevada, Colorado, and North Carolina were considered swing states.

6 The threshold for 'low' family income differs depending on the number of family members. Thus, instead of setting an arbitrary threshold for the low family income variable, I use respondents' level of family income.

7 Income categories are: 1) less than $\$ 10,000 ; 2) 10,000$ to under $\$ 20,000 ; 3) 20,000$ to under $\$ 30,000$; 4) 30,000 to under $\$ 40,000$; 5) 40,000 to under $\$ 50,000 ; 6)$ 50,000 to under $\$ 75,000 ; 7)$ $75,000$ to under $\$ 100,000 ; 8) 100,000$ to under $\$ 150,000$; and 9) $\$ 150,000$ or more. 
ideology, party identification, and evaluations of personal and national economic conditions. Respondents' general political ideology is measured using a five-point scale ( $1=$ very liberal, $5=$ =very conservative). Party identification is measured with two dummy variables using 'independents' as a baseline. That is, Republicans and Democrats are coded one (1) in each dummy variable.

To operationalize individual evaluations of the national economy, I employ the following question: "Would you rate economic conditions in this country today as excellent, good, only fair, or poor?" The evaluation of an individual's personal economy is measured based on the following question: "How would you rate your own personal financial situation? Would you say you are in excellent shape, good shape, only fair shape, or poor shape financially?" The scale of these two variables ranges from one (poor) to four (excellent).

As for controlling variables, I employ income measured by respondents' family income. I also include gender, age, and race as demographic factors.

\section{FINDINGS AND DISCUSSION}

Table 5 reports the empirical results. The columns of Model 1 display the results without the two interaction terms. As shown in Table 5, the sector effect measured by a state's share of manufacturing employment is significantly related to the American public's attitudes toward free trade agreements. Those who live in a state with a higher share of manufacturing employment are more likely to be protectionists. In contrast, the skills as measured by the level of education have no impact on individual preferences regarding free trade agreements. Mayda and Rodrik (2005) find skill levels measured by year of education have a significantly positive impact on support for open trade policy. Yet, my results reveal that the highly skilled do not favor free trade, while the unskilled are not protectionists. These results suggest that individuals do not significantly consider their own productive factor endowments. Why then do skills have no impact?

One of the possible reasons may be the characteristics of U.S. trading partners. The top 10 largest trading partners of the United States include China, Mexico, Canada, Germany, Japan, South Korea, the United Kingdom, France, India, and Taiwan. As with the United States, most of those trading partners also are skill-abundant countries. Thus, the American public may not expect to gain comparative advantages on a large enough scale through free trade in terms of mobile factor endowments. As a result, American attitudes toward free trade agreements may not rely on the level of skills. Taken together, my findings indicate that American attitudes toward free trade are constrained by 
the industrial features of states more so than by individuals' considerations of personal advantages.

Table 5. Determinants of American Attitudes toward Free Trade Agreements

\begin{tabular}{|c|c|c|c|c|}
\hline & \multicolumn{2}{|c|}{ Model 1} & \multicolumn{2}{|c|}{ Model 2} \\
\hline & Coefficient & Marginal & Coefficient & Marginal \\
\hline \multicolumn{5}{|l|}{ Economic factors } \\
\hline Skill level & $\begin{array}{l}.006 \\
(0.19)\end{array}$ & .001 & $\begin{array}{l}.007 \\
(0.23)\end{array}$ & .002 \\
\hline Sector effects & $\begin{array}{l}-.037^{*} \\
(-2.26)\end{array}$ & -.008 & $\begin{array}{l}-.038^{*} \\
(-2.31)\end{array}$ & -.008 \\
\hline \multicolumn{5}{|l|}{ Psychological factors } \\
\hline Ideology & $\begin{array}{c}-.037 \\
(-0.61)\end{array}$ & -.008 & $\begin{array}{l}-.027 \\
(-0.44)\end{array}$ & -.006 \\
\hline Republicans & $\begin{array}{l}.103 \\
(0.71)\end{array}$ & .024 & $\begin{array}{l}.100 \\
(0.69)\end{array}$ & .023 \\
\hline Democrats & $\begin{array}{l}.077 \\
(0.57)\end{array}$ & .018 & $\begin{array}{l}.054 \\
(0.40)\end{array}$ & .012 \\
\hline $\begin{array}{l}\text { Evaluation of } \\
\text { national economy }\end{array}$ & $\begin{array}{l}.439^{* * *} \\
(5.78)\end{array}$ & .100 & $\begin{array}{l}.450 * * * \\
(5.90)\end{array}$ & .103 \\
\hline $\begin{array}{l}\text { Evaluation of } \\
\text { personal economic } \\
\text { situation }\end{array}$ & $\begin{array}{l}.106 \\
(1.37)\end{array}$ & .024 & $\begin{array}{c}.098 \\
(1.26)\end{array}$ & .022 \\
\hline \multicolumn{5}{|l|}{ Controls } \\
\hline Whites & $\begin{array}{l}1.151^{* *} \\
(2.69)\end{array}$ & .263 & $\begin{array}{l}1.319^{* *} \\
(2.97)\end{array}$ & .301 \\
\hline African Americans & $\begin{array}{l}.943^{*} \\
(2.06)\end{array}$ & .216 & $\begin{array}{l}.966^{*} \\
(2.09)\end{array}$ & .220 \\
\hline Asian Americans & $\begin{array}{l}1.066^{*} \\
(1.91)\end{array}$ & .243 & $\begin{array}{l}.927 \\
(1.74)\end{array}$ & .211 \\
\hline Latinos & $\begin{array}{l}1.498^{* *} \\
(3.03)\end{array}$ & .342 & $\begin{array}{l}1.454^{* *} \\
(2.67)\end{array}$ & .344 \\
\hline Income & $\begin{array}{l}-.003 \\
(-0.12)\end{array}$ & .001 & $\begin{array}{c}.019 \\
(0.56)\end{array}$ & .004 \\
\hline White/ male/ income & & & $\begin{array}{l}-.075^{*} \\
(-2.16)\end{array}$ & -.017 \\
\hline Millennials/ income & & & $\begin{array}{l}.084^{* *} \\
(2.70)\end{array}$ & .019 \\
\hline Age & $\begin{array}{l}-.012^{\star \star *} \\
(-3.99)\end{array}$ & -.003 & $\begin{array}{l}-0.005 \\
(-1.13)\end{array}$ & -.001 \\
\hline Gender & $\begin{array}{c}-.065 \\
(-0.58)\end{array}$ & -.015 & $\begin{array}{l}0.206 \\
(1.10)\end{array}$ & .059 \\
\hline $\begin{array}{l}\text { N } \\
\text { R2_McFadden } \\
\text { BIC }\end{array}$ & 1566 & 0.0431 & & \\
\hline
\end{tabular}

Note: $t$ statistics in parentheses. ${ }^{*} p<0.05,{ }^{* *} p<0.01,{ }^{* * *} p<0.001$. Marginal: marginal effect 
Mansfield and Mutz (2009) find that American attitudes toward free trade were not substantially related to party identification. My results confirm their findings. That is, American attitudes toward free trade deals are determined neither by partisanship nor by ideology. This finding implies that the protectionism sloganeering during the 2016 election did not effectively mobilize voters in terms of party identification. Among the other psychological factors employed, the evaluation of personal economy is not related to an individual's support for free trade deals. In contrast, individual evaluations of the national economy have a strong and positive effect. These results imply that the American public evaluates free trade agreements in light of national considerations but not based on their personal economic situations.

Among demographic factors, race determines individual trade preferences. Individuals belonging to major minority racial groups in the United States tend to have positive attitudes toward free trade agreements. During the 2016 campaign, it was often mentioned that Trump's protectionist position garnered extensive support from whites. However, my evidence reveals that whites are more likely to support free trade agreements. Both Latinos and African American also have positive attitudes toward free trade agreements. Asian Americans are more likely to support free trade agreements only when the two interaction terms are not considered.

Age acquires statistical significance. The older are more likely to be protectionists than the younger. However, when the two interaction terms are employed, the effect becomes null. Instead, millennials are less pro-trade if their family income tets lower (see Model 2). Nevertheless, they are not protectionists regardless of income level. In sum, the results related to the age variable clearly show that the young are less likely to be protectionists.

In both models, income alone is not related to Americans' support for free trade deals. No impact of income only suggests that economic status itself does not necessarily inform Americans' preferences for free trade agreements. In contrast, as shown in Model 2, income has an impact when it is interacted with age, race, and gender. Specifically, millennials are more positive toward free trade agreements when their family income is higher. In contrast, white males are less positive about free trade when their family income is higher. The latter finding is noticeable. During the 2016 election campaign, the media and political commentators often claimed that working-class white males, who were likely to have a low level of family income, had stronger support for protectionist policies. My finding partly supports that claim. White males are protectionists. However, white males with higher-not lower-family income are more likely to be protectionists. In short, white males with higher income are more likely to feel a 
sense of insecurity from free trade agreements.

\section{CONCLUSION}

The public is known to pay little attention to trade policies such as free trade agreements (Knecht and Weatherford 2006; Kono 2008; Milner and Tingley 2011; Scheve and Slaughter 2001). However, protectionism was central to American political discourse during the entire 2016 election campaign. Who are the protectionists in the United States? My evidence reveals that American attitudes toward free trade agreements are decided not by their levels of skills but by the industrial feature of the region in which they live. Protectionists live in states with high shares of manufacturing employment. My findings also demonstrate that income in relation to race and age plays a significant role. However, political predispositions, as psychological factors, do not explain American attitudes toward free trade deals.

In the context of the 2016 presidential election, my findings imply that Trump's protectionist positions worked for Americans living in states with high percentages of manufacturing employment. However, his protectionist rhetoric was not so successful in mobilizing perceived swing voters. According to the swing voter model, partisans will vote according to party labels. Therefore, presidential candidates and their campaign strategists are more likely to focus their campaign resources on uncommitted voters who rely not on party identification but on other cues when deciding their vote choices. However, swing voters differ according to particular electoral contexts. Also, candidates do not attempt to persuade every kind of swing voters with one policy proposal or campaign slogan. Particular policy proposals tend to target specific segments of swing voters. In the 2016 election, Trump's protectionist positions were expected to mobilize economically insecure swing voters, such as the young and white males with low family income. My findings, however, indicate they are not protectionists even when party identification is controlled. Specifically, my evidence show that the young are supportive of free trade agreements even when taking into account the level of their family income. This implies that the protectionist rhetoric of the 2016 election may have made little contribution to convincing the young, even those with low family income.

Lastly, I find that those who evaluate the state of the national economy negatively are more likely to be protectionists. This indicates that a sense of economic insecurity about the nation as a whole guided American voters during the 2016 election. Therefore, if the U.S. economy does not improve to such an 
extent that the public perceives the economy as healthy, much of that public will be likely to continue to support Trump's protectionist stance.

\section{REFERENCES}

Allport, Gordon W. 1954. The Nature of Prejudice. Reading, MA: AddisonWesley Publishing Company.

Baker, Andy. 2005. "Who Wants to Globalize? Consumer Tastes and Labor Markets in a Theory of Trade Policy Beliefs." American Journal of Political Science 49(4), 924-938.

Beaulieu, Eugene, Ravindara, Yatawara, and Wang Wei Guo. 2005. "Who Support Free Trade in Latin America?” The World Economy 28(7), 941959.

Campbell, Angus, Philip E. Converse, Warren E. Miller, and Donald E. Stokes. 1960. The American Voter. Chicago, IL: University of Chicago Press.

Campbell, Angus, Gerald Gurin, and Warren E. Miller. 1954. The Voter Decides. Westport, CT: Greenwood.

Campbell, Andrea Louise, Cara Wong, and Jack Citrin. 2006. “'Racial Threat', Partisan Climate and Direct Democracy: Contextual Effects in Three California Initiatives." Political Behavior 21(1), 1-16.

Campbell, James. 2007. "Do Swing Voters Swing Elections?” In William G. Mayer ed., The Swing Voter in American Politics. Washington, D.C.: Brookings Institution Press, 118-132.

Citrin, Jack, Cara Wong, and Brian Duff. 2001. "The Meaning of American National Identity: Pattern of Ethnic Conflict and Consensus." In

Richard D. Ashmore, Lee Jussim, and David Wilder eds., Social Identity, Intergroup Conflict and Conflict Resolution. Oxford: Oxford University Press, 71-100.

Converse, Philip E. 1960. "The Nature of Belief Systems in Mass Publics.” In David E. Apter ed., Ideology and Discontent. New York Free Press of Glencoe.

Daniels, Joseph P. and Marc von der Ruhr. 2003. "The Determinants of Immigration-Policy Preferences in Advanced Economies: A CrossCountry Study." Atlantic Economic Journal 31(2), 146-158

De Figueredo, Rui J.P., and Zachary Elkins. 2003. "Are Patriots Bigots? An Inquiry into the Vices of In-group Pride.” American Journal of Political Science 47(1), 171-188.

Hainmueller, Jens and Michael J. Hiscox. 2006. "Learning to Love 
Globalization: The Effects of Education on Individual Attitudes towards International Trade." International Organization 6o(2), 469-498.

Hays, Jude C., Sean D. Enrlich, and Clint Peihhardts. 2005. "Government Spending and Public Support for Trade in the OECD: An Empirical Test of the Embedded Liberalism Thesis." International Organization 59(2), 473-494.

Hiscox, Michael. 2006. "Through a Glass and Darkly: Attitudes Toward International Trade and the Curious Effects of Issue Framing." International Organization 6o(3), 755-780.

Hopkins, Daniel. 2010. "Politicized Places: Explaining Where and When Immigrants Provoke Local Opposition.” American Political Science Review 104(1), 40-60.

Kaltenthaler, Karl, Ronald Gellenery, and Stephen Ceccoli. 2004. "Explaining Citizen Attitudes toward Trade Liberalization." International Studies Quarterly 48(4), 829-851.

Key, V.O. 1949. Southern Politics in State and Nation. Knoxville, TN: University of Tennessee Press.

Knecht, Thomas and M. Stephen Weatherford. 2006. "Public Opinion and Foreign Policy: The Stages of Presidential Decision Making." International Studies Quarterly 50(3), 705-727.

Kono, Daniel Y. 2008. "Does Public Opinion Affect Trade Policy?” Business and Politics 10(2), 1-19.

McCarty, Nolan, Keith T. Poole, and Howard Rosenthal. 2006. Polarized America: The Dance of Ideology and Unequal Riches. Cambridge, MA: MIT Press.

Mansfield, Edward D. and Diana C. Mutz. 2009. "Support for Free Trade: SelfInterest, Sociotropic Politics, and Out-Group Anxiety." International Organization 63(3), 425-457.

Mayda, Anna and Rodrik Dani. 2005. "Why are Some People (and Countries) More Protectionist than Others?” European Economic Review 49(6), 1393-1430.

Mayda, Anna. 2007 "Why are People More Pro-trade than Pro-migration?" IZA Discussion Paper No. 2855. Accessed at http://ssrn.com/ abstract $=998443$ (October 1, 2016).

Mayer, William G. 1996. The Divided Democrats: Ideological Unity, Party Reform and Presidential Elections. Boulder, CO: Westview Press. 2007. The Swing Voter in American Politics. Washington D.C: Brookings Institute Press.

Milner, Helen V. and Dustin H. Tingley. 2011. "Who Supports Global 
Economic Engagement: The Sources of Preferences in American Foreign Economic Policy." International Organization 65(Winter), 3768.

O'Rourke, Kevin H., and Richard Sinnott. 2001. "The Determinants of Individual Trade Policy Preferences." International Survey Evidence Brookings Trade Forum, 157-206. 2006. "The Determinants of Individual Attitudes towards Immigration." European Journal of Political Economy 22(4), 838-861.

O' Rourke, Kevin H., and Taylor Alan. 2006. "Democracy and Protectionism." National Bureau of Economic Research Working Paper 12250.

Scheve, Kenneth F. and Matthew J. Slaughter. 2001. What Determines Individual Trade-Policy Preferences? Journal of International Economics 54(2), 267-292.

Schissel, Bernard, Richard Wanner, and James Frideres. 1989. "Social and Economic Context and Attitudes toward Immigrants in Canadian Cities." International Migration Review 23(2), 289-308.

Sides, John and Jack Citrin. 2007. "European Opinion about Immigration: The Role of Identities, Interests and Information." British Journal of Political Science 37(3), 477-504.

[Received February 10, 2017; Revised July 11, 2017; Accepted August 1, 2017] 